\title{
Selected soil thermal conductivity models
}

\author{
Monika Rerak $^{1, *}$ \\ ${ }^{1}$ Cracow University of Technology, Institute of Thermal Power Engineering, al. Jana Pawła II 37, 31-864 Krakow, Poland
}

\begin{abstract}
The paper presents collected from the literature models of soil thermal conductivity. This is a very important parameter, which allows one to assess how much heat can be transferred from the underground power cables through the soil. The models are presented in table form, thus when the properties of the soil are given, it is possible to select the most accurate method of calculating its thermal conductivity. Precise determination of this parameter results in designing the cable line in such a way that it does not occur the process of cable overheating.
\end{abstract}

\section{Introduction}

When designing the underground power cable system it is important to ensure its safe operation [1-5]. The cable line shall be designed in such a way to not exceed the safe operating temperature. What is also important is the economic aspect of the cable system installation. To best meet the safety conditions and the cost-effectiveness the heat dissipation from the power cables to the surrounding soil should be properly evaluated.

In the literature there are several methods that aim to provide the soil thermal conductivity values. Many of them are based primarily on the moisture content of the soil. Soils are divided into five types: gravel, loam, clay, peat and sand. This division corresponds to the categorization used by the Unified Soil Classification System. The soils exhibit two states: the frozen and unfrozen. The methods described below also take into account the effect of the soil dry density [6].

\section{Van Rooyen and Winterkorn model}

The first method presented in this work was developed by Van Rooyen and Winterkorn. This is an empirical relationship. It is used to determine the thermal conductivity of sand and gravel. It can be applied to the non-frozen soil, where the water content is between $1.5 \%$ and $10 \%$.

$$
\frac{1}{k}=A \cdot 10^{-B S_{r}}+s
$$

Where:

$\mathrm{k}$ - soil thermal conductivity $[\mathrm{W} / \mathrm{m} \cdot \mathrm{K}]$,

$\mathrm{S}_{\mathrm{r}}-$ water content [\%],

A - function of soil dry density,

B - mineral type,

$\mathrm{s}-$ granulometry.
Applying the above equation is not straightforward due to additional variables, which also one must determine (A, B and s). The selection of suitable parameters is complicated, and therefore the correct calculation of the thermal conductivity is difficult [7].

\section{Johansen model}

Another relationship was reported by Johansen. It can be used for soils both coarse and fine-grained in frozen or unfrozen state. The maximum water content for this method is $20 \%$ [8,9]. Johansen's equation becomes:

$$
k=\left(k_{s a t}-k_{D}\right) \cdot k_{e}+k_{D}
$$

where:

$\mathrm{k}_{\mathrm{sat}}$ - saturated soil thermal conductivity $[\mathrm{W} / \mathrm{m} \cdot \mathrm{K}]$,

$\mathrm{k}_{\mathrm{D}}-$ dry thermal conductivity of the soil $[\mathrm{W} / \mathrm{m} \cdot \mathrm{K}]$,

$\mathrm{k}_{\mathrm{e}}-$ function of soil saturation level [-].

The disadvantage of this method is fact that it does not account moisture migration. This attribute can have a significant impact on the effective thermal conductivity.

\section{De Vries model}

Next model was developed by De Vries. This method assumes that the soil is a two-phase material. It consists of a uniform, solid particles, which have an elliptical shape. These particles are dispersed in a liquid phase. This method can be used for the water content in the range of $10 \%$ to $20 \%$. The soil must be coarse and not frozen [10,11]. De Vries formula on soil thermal conductivity is expressed by:

$$
k=\frac{x_{f} \cdot k_{f}+F \cdot x_{s} \cdot k_{s}}{x_{f}+F \cdot x_{s}}
$$

\footnotetext{
* Corresponding author: monika.rerak@mech.pk.edu.pl
} 
where:

$\mathrm{f}$ - liquid phase,

$\mathrm{s}$ - solid phase,

$\mathrm{x}$ - volume fraction,

and:

$$
F=\frac{1}{3} \sum_{i}\left[1+\left[\frac{k_{s}}{k_{f}}-1\right] g_{i}\right]^{-1}
$$

where the values of $g_{i}$ sum to unity. The parameter $F$ was originally supposed to be the aspect ratio, but now its values are used to fit the empirical data $[7,8,12,13]$.

This method assumes particles that are not in contact and this is contrary to the general condition in soils.

\section{Kersten model}

Another formula for soil thermal conductivity is Kersten's model. The model is successfully used for various soil types. It was created based on the relationships that were derived from empirical data. This model is widely used due to the derivation of equations for the frozen and unfrozen sandy soils and the soils formed of silt and clay. The Kersten's formula can be applied to sandy soils with water content higher than $1 \%$, and for soils consisting of silt and clay with water content higher than 7\%. It should be noted that Kersten's correlation gives the correct results only for frozen soils with a maximum water content of $90 \%[14,15]$.

Correlation for sandy soils:

- unfrozen soil

$$
k=[0.101 \log w+0.0577] 10^{0.000624 \rho_{d}}
$$

-frozen soil

$$
k=0.011(10)^{0.000812 \rho_{d}}+0.00462(10)^{0.000911 \rho_{d} \cdot w}
$$

The correlation for soils consisting of loam and clay: - unfrozen soil

$$
\mathrm{k}=[0.13 \log \mathrm{w}-0.0288] 10^{0.000624 \rho_{\mathrm{d}}}
$$

- frozen soil

$$
k=0.00144(10)^{0.00137 \rho_{d}}+0.0123(10)^{0.000499 \rho_{d} \cdot w}
$$

where:

$\mathrm{k}$ - soil thermal conductivity $[\mathrm{W} / \mathrm{m} \cdot \mathrm{K}]$,

$\mathrm{w}$ - water content [\%],

$\rho_{d}-$ dry density of the soil $\left[\mathrm{kg} / \mathrm{m}^{3}\right]$.

Experiments conducted in order to verify the above method led to the conclusion that this method is valid and recommended for soils with low clay and loam content $(20 \%)$. It works very well also for soil primarily consisting of quartz $[7,8]$.

Figures 1 and 2 illustrate the results obtained by the Kersten's model. One can observe the impact on the soil thermal conductivity of water content and bulk density in the dry state. Using the charts presented above, for a given soil properties, one can determine the thermal conductivity value $[16,17]$.

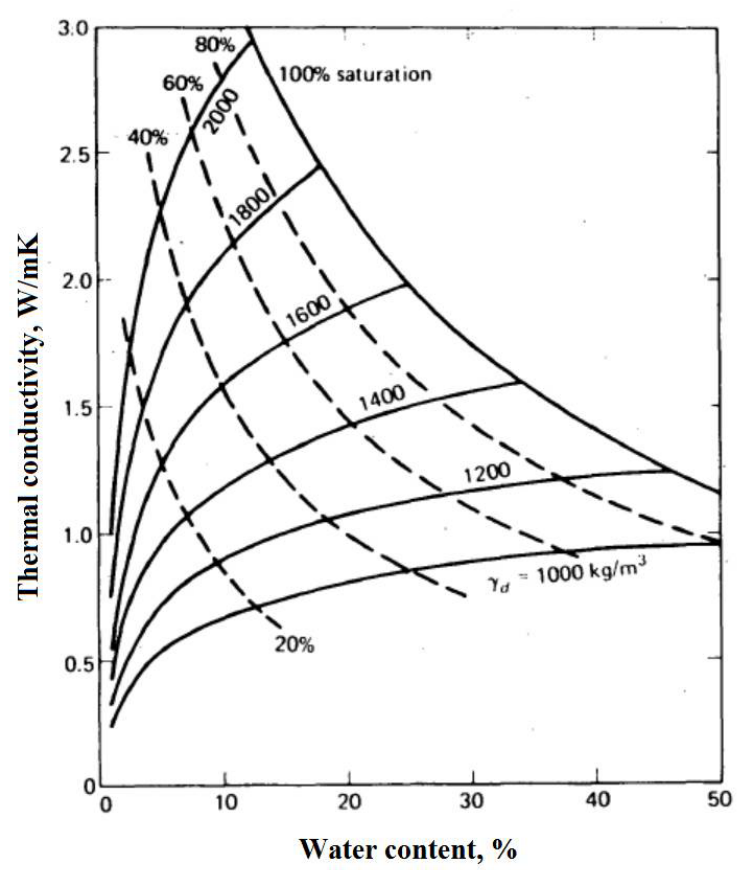

Fig. 1. The average thermal conductivity of the non-frozen sandy soil as a function of water content and the density in the dry state [7].

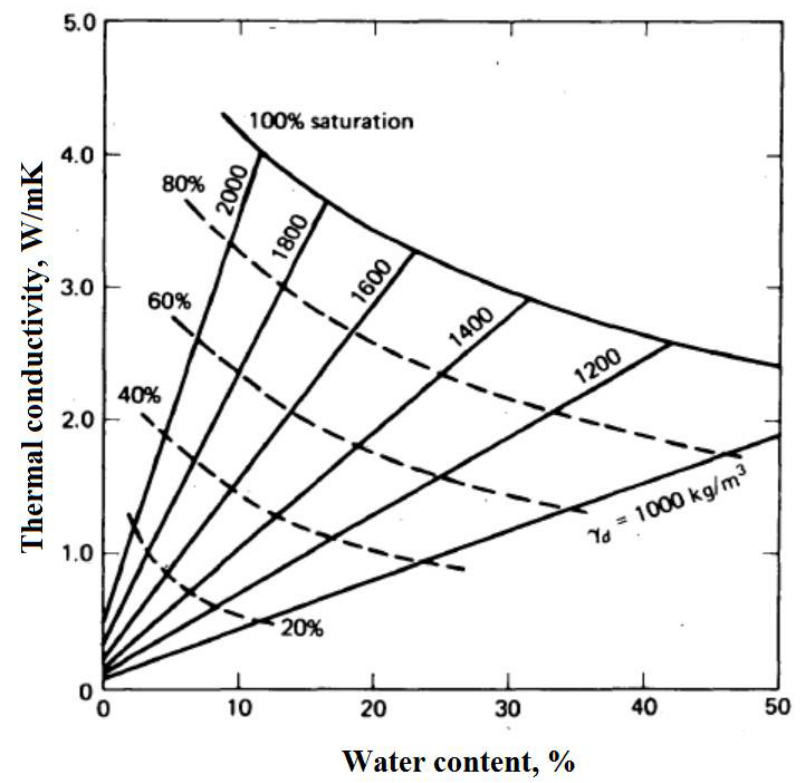

Fig. 2. The average thermal conductivity of the frozen sandy soil as a function of water content and the density in the dry state [7]. 


\section{Gemant model}

Another correlation for determining the soil thermal conductivity was proposed by Gemant. His model is based on the idealized shape of the soil particle. Gemant assumed that the particle has designated contact points around which the water is gathered. The contact points form thermal bridges. Based on the heat flow through thermal bridges the soil thermal conductivity is calculated $[8,11,18]$ :

$$
\begin{gathered}
\frac{1}{k}=\frac{\left[\frac{(1-a)}{a}\right]^{\frac{4}{3}} \tan ^{-1}\left[\frac{\left(k_{S}-k_{W}\right)}{k_{W}}\right]^{\frac{1}{2}}}{\left(\frac{h}{2}\right)^{\frac{1}{3}}\left[k_{w}\left(k_{S}-k_{w}\right)\right]^{\frac{1}{2}}}+\frac{(1-z)}{k_{S} a} f\left\{\frac{b^{2}}{a}\right\} \\
a=0.078 s^{\frac{1}{2}} \\
h=0.16 \cdot 10^{-3} S \cdot w-h_{0} \\
Z=\left(\frac{1-a}{a}\right)^{\frac{1}{2}}\left(\frac{h}{2}\right)^{\frac{1}{3}} \\
b^{2}=\left(\frac{a}{1-a}\right)^{\frac{2}{3}}\left(\frac{h}{2}\right)^{\frac{2}{3}}
\end{gathered}
$$

where :

$\mathrm{k}_{\mathrm{s}}$ - the thermal conductivity of the solids $[\mathrm{W} / \mathrm{m} \cdot \mathrm{K}]$,

$\mathrm{k}_{\mathrm{w}}$ - the thermal conductivity of water $[\mathrm{W} / \mathrm{m} \cdot \mathrm{K}]$,

$\mathrm{h}$ - apex water (water collected around the contact points),

$\mathrm{h}_{\mathrm{o}}$ - water absorbed as a film around the soil particles,

$\mathrm{s}-$ soil dry density $\left[\mathrm{lb} / \mathrm{ft}^{3}\right]$,

$\mathrm{w}$ - water content $[\%]$,

$\mathrm{a}, \mathrm{b}, \mathrm{z}-$ shape functions.

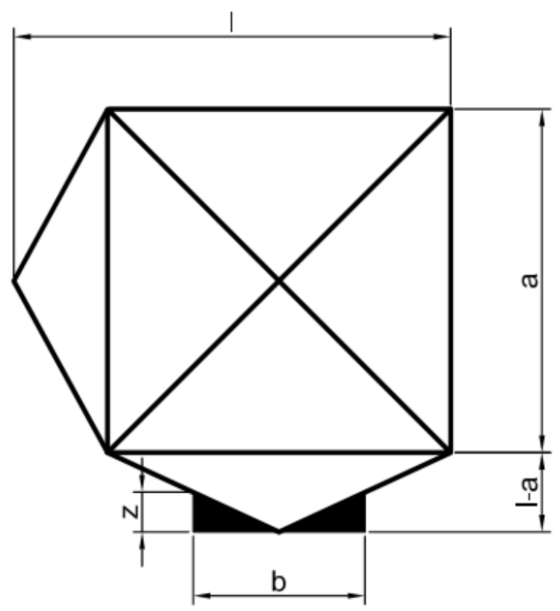

Fig.3. Idealized model of the soil particle [7].

\section{Conclusions}

Farouki [7] recommended the application ranges of the various soil thermal conductivity models. The validation ranges are given in Table 1 . This table was created based on the experimental investigation for various soil state, textures, and water content [19-21]. As one can see, each method cannot be applied to all types of soils. So there is no single methodology that can be used. Therefore, the use of these methods in numerical algorithms related to the heat transfer needs to apply special conditions. The table allows you to choose the

\begin{tabular}{|c|c|c|c|}
\hline State & Teksture & $\begin{array}{l}\text { Water } \\
\text { content }\end{array}$ & $\begin{array}{c}\text { Correlation for } \\
\text { thermal } \\
\text { conductivity } \\
\text { calculation }\end{array}$ \\
\hline \multirow{9}{*}{ 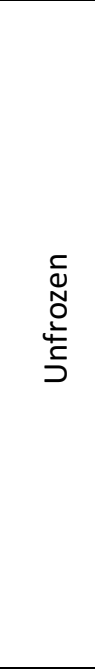 } & \multirow{5}{*}{$\begin{array}{c}\text { Coarse } \\
\text { soil }\end{array}$} & $0,015-0,100$ & $\begin{array}{c}\text { Van Rooyen and } \\
\text { Winterkorn }\end{array}$ \\
\hline & & $0,100-0,200$ & De Vries \\
\hline & & $0,200-1,000$ & Johansen \\
\hline & & $0,000-1,000$ & Gemant \\
\hline & & $\begin{array}{l}\text { Saturated } \\
\text { state }\end{array}$ & $\begin{array}{c}\text { Johansen, De Vries, } \\
\text { Gemant }\end{array}$ \\
\hline & \multirow{4}{*}{ Fine soil } & $0,000-0,100$ & $\begin{array}{c}\text { Johansen } \\
\text { (error 15\%) }\end{array}$ \\
\hline & & $0,100-0,200$ & $\begin{array}{l}\text { Johansen } \\
\text { (error 5\%) }\end{array}$ \\
\hline & & $0,200-1,000$ & Johansen \\
\hline & & $\begin{array}{c}\text { Saturated } \\
\text { state }\end{array}$ & $\begin{array}{c}\text { Johansen, De Vries, } \\
\text { Gemant }\end{array}$ \\
\hline \multirow{5}{*}{$\begin{array}{l}\text { d } \\
\text { N } \\
\text { 는 }\end{array}$} & \multirow{2}{*}{$\begin{array}{c}\text { Coarse } \\
\text { soil }\end{array}$} & $0,100-1,000$ & Johansen \\
\hline & & $\begin{array}{l}\text { Saturated } \\
\text { state }\end{array}$ & Johansen, De Vries \\
\hline & \multirow{3}{*}{ Fine soil } & $0,000-0,900$ & Kersten \\
\hline & & $0,100-1,000$ & Johansen \\
\hline & & $\begin{array}{l}\text { Saturated } \\
\text { state }\end{array}$ & Johansen, De Vries \\
\hline
\end{tabular}
best method. Choosing the appropriate method allows to reduce the error.

Table 1. Application ranges for various soil thermal conductivity correlations [7].

\section{References}

1. P. Ocłoń, M. Bittelli, P. Cisek, E. Kroener, M. Pilarczyk, D. Taler, R.V. Rao, A. Vallati, The performance analysis of a new thermal backfill material for underground power cable system Applied Thermal Engineering, 108, pp. 233-250 (2016)

2. P. Ocłoń, P. Cisek, D. Taler, M. Pilarczyk, T. Szwarc, Optimizing of the underground power cable bedding using momentum-type particle swarm optimization method Energy, 92, pp. 230239 (2015)

3. P. Ocłoń, P. Cisek, M. Pilarczyk, D. Taler, Numerical simulation of heat dissipation processes in underground power cable system situated in thermal backfill and buried in a multilayered soil Energy Conversion and Management, 95, pp. 352$370(2015)$ 
4. P. Ocłoń, D. Taler, P. Cisek, M. Pilarczyk, FemBased Thermal Analysis of Underground Power Cables Located in Backfills Made of Different Materials Strength of Materials, 47 (5), pp. 770780 (2015)

5. P. Cisek, P. Ocłoń, M. Pilarczyk. Thermal analysis of operating conditions for The $400 \mathrm{kV}$ underground power cable transmission line as a power plant delivery system. Rynek Energii; 114:70-7 [in polish] (2014)

6. E. Kroener, A. Vallati, M. Bittelli, Numerical simulation of coupled heat, liquid water and water vapor in soils for heat dissipation of underground electrical power cables. App Therm Eng; 70:51023 (2014)

7. O.T. Farouki: Thermal properties od soils, Series Rock Soil Mech, (1986)

8. B.R. Becker, B.A. Fricke: Effects of saturation and dry density on soil thermal conductivity, (1997)

9. M. Bittelli, G. S. Campbell, F. Tomei; Transport in the Soil-Plant-Atmosphere System, Oxford University Press (2015)

10. G.S. Campbell, J.R. Jungbauer, W.R. Bidlake, R.D. Hungerford. Predicting the effect of temperature on soil thermal conductivity. Soil Sci; 5:307-13 (1994)

11. B. Usowicz, J. Lipiec, J.B Usowicz, W. Marczewski. Effects of aggregate size on soil thermal conductivity: Comparison of measured and model-predicted data. Int J Heat Mass Tran, 2:536-41 (2013)

12. D.A. De Vries, N.H. Afgan. Heat and mass transfer in the biosphere. John Wiley and Sons; (1975)
13. D.A. De Vries. Thermal properties of soils. In: Van Wijk WR, editor. Physics of plant environment. Amsterdam: North-Holland Publishing Company; p. 210-35. (1963)

14. ISO 14688-2, Geotechnical investigation and testing - Identification and classification of soil Part 2: Principles for a classification.

15. M.S. Kersten. Thermal properties of soil. Bull Univ Minn Inst Technol 52:1-225 (1949)

16. M. Bittelli, F. Ventura, G.S. Campbell, R.L. Snyder, F. Gallegati, P.R. Pisa. Coupling of heat, water vapor, and liquid water fluxes to compute evaporation in bare soils. J Hydrol 3-4:191-205 (2008)

17. F. Gori, S. Corasaniti . New model to evaluate the effective thermal conductivity of three-phase soils. Int Commun Heat Mass 47:1-6 (2013)

18. A.R. Sepaskhah, L.Boersma. Thermal conductivity of soils as a function of temperature and water content. Soil Sci Soc Am J, 43:439-44 (1979)

19. T. Kasubuchi. Heat conduction model of saturated soil and estimation of thermal conductivity of soil solid phase. Soil Sci, 138:240-7 (1984)

20. V.R. Tarnawski, T. Mosome, W.H. Leong, G. Bovesecchi, P. Coppa. Thermal conductivity of standard sands. Part I. Dry-state conditions. Int J Thermophys, 30:949-68 (2009)

21. C.D. Peters-Lidard, E. Blackburn, X. Liang, E.F. Wood. The effect of soil thermal conductivity parameterization on surface energy fluxes and temperatures. J Atmos Sci, 55:1209-24 (1998) 